\title{
DIETS WITH REDUCED LEVELS OF NUTRIENTS SUPPLEMENTED WITH PHYTASE AND AMINO ACIDS FOR BROILERS
}

\author{
Dietas com reduzidos níveis de nutrientes, suplementadas \\ com fitase e aminoácidos, para frangos de corte
}

\author{
Elisangela Minati Gomide', Paulo Borges Rodrigues ${ }^{2}$, Luciana de Paula Naves ${ }^{2}$, \\ Verônica Maria Pereira Bernardino ${ }^{2}$, Luziane Moreira dos Santos², Antonio Amandio Pinto Garcia ${ }^{2}$
}

\begin{abstract}
One performance experiment and another metabolism experiment were conducted simultaneously with broilers from 22 to 35 days of age, evaluating five diets in six replicates. The control diet, without phytase, contained $19 \%$ of crude protein (CP); $0.412 \%$ of available phosphorus $(\mathrm{aP})$ and $0.824 \%$ of calcium $(\mathrm{Ca})$. The other diets were supplemented with phytase and were formulated with $0.262 \%$ of aP and $0.524 \%$ of $\mathrm{Ca}$, with the $\mathrm{CP}$ level ranging from 19 to $16 \%$. In the performance assay, 750 birds were used, in which were evaluated the performance, the tibia ash content and yields of carcass, cuts, and abdominal fat at 35 days of age. The metabolism assay was conducted with 90 birds, evaluating the apparent metabolizable energy corrected by the nitrogen balance; the metabolizability coefficient of dry matter (MCDM) of the diets, and also the balance and retention of nitrogen $(\mathrm{N})$ and phosphorus $(\mathrm{P})$. Diets did not affect performance, tibia ash content and yields of carcass, breast and thigh + drumstick. However, birds fed diet containing $16 \%$ of CP showed greater abdominal fat. Diets containing $19 \%$ of CP had the smaller energetic value and MCDM. The retention of $\mathrm{N}$ and $\mathrm{P}$ was higher in birds fed diets formulated with reduced $\mathrm{CP}$ content and phytase. Therefore, when the broiler feed is supplemented with phytase and amino acids it is possible to reduce the $\mathrm{CP}$, aP and $\mathrm{Ca}$ for up to $16 ; 0.262$ and $0.524 \%$, respectively.
\end{abstract}

Index terms: Tibia ash, carcass yield, ideal protein, metabolism, performance.

\section{RESUMO}

Um experimento de desempenho e outro de metabolismo foram conduzidos simultaneamente com frangos de corte de 22 a 35 dias de idade, avaliando-se cinco dietas em seis repetições. A dieta controle, sem fitase, continha $19 \%$ de proteína bruta (PB); 0,412\% de fósforo disponível (Pdisp) e 0,824\% de cálcio (Ca). As demais dietas foram suplementadas com fitase e formuladas com 0,262\% de Pdisp e 0,524\% de Ca, tendo o teor de PB variado em 19 até $16 \%$. No ensaio de desempenho, 750 aves foram utilizadas, avaliando-se o desempenho, o teor de cinzas na tíbia e rendimentos de carcaça, cortes e gordura abdominal, aos 35 dias de idade. O ensaio de metabolismo foi realizado com 90 aves, determinando-se a energia metabolizável aparente, corrigida pelo balanço de nitrogênio e o coeficiente de metabolizabilidade da matéria seca (CMMS) das rações, e também o balanço e retenção de nitrogênio $(\mathrm{N})$ e fósforo $(\mathrm{P})$. As dietas não influenciaram o desempenho, teor de cinzas na tíbia e os rendimentos de carcaça, peito e coxa + sobrecoxa. Entretanto, as aves alimentadas com a ração contendo 16\% de PB apresentaram maior teor de gordura abdominal. As rações com 19\% de PB apresentaram menor valor energético e CMMS. A retenção de $\mathrm{N}$ e $\mathrm{P}$ foi maior nas aves que receberam as rações com reduzidos teores de PB e fitase. Portanto, quando a ração de frangos de corte é suplementada com fitase e aminoácidos é possível reduzir a PB, Pdip e Ca em até 16; 0,262 e 0,524\%, respectivamente.

Termos para indexação: Cinza na tíbia, rendimento de carcaça, proteína ideal, metabolismo, desempenho.

(Received in june 6, 2011 and approved in november 7, 2011)

\section{INTRODUCTION}

The reduction of nutrients contents in the diet of broilers is desirable due to matters of economical and environmental scope. Decrease the inclusion of expensive ingredients in the diet, like soybean meal and inorganic phosphate, means to increase profits by reducing the costs with the feed of birds. On the other hand, reduce the nitrogen $(\mathrm{N})$ and phosphorus $(\mathrm{P})$ in the excreta represents an advance in the livestock production in a sustainable way, since these nutrients present in the excreta, will normally go to the soil and can be taken into water bodies causing the eutrophication of these important habitats (SELLEet al., 2009).

\footnotetext{
1Universidade Federal de Lavras - Departamento de Zootecnia - Cx. P. 3037 - 37200-000 - Lavras - MG - Brasil - elis.zoo@hotmail.com Universidade Federal de Lavras - Departamento de Zootecnia - Lavras - MG - Brasil
} 
An efficient way to reduce the $\mathrm{N}$ excretion is to reduce its intake, thus, the dietary crude protein is decreased followed by the addition of synthetic amino acids (CORZO et al., 2005; GOMIDE et al., 2011). In order to decrease the excretion of $\mathrm{P}$ it is necessary to reduce the level of phosphate in the diet and increase the efficiency utilization of the dietary P by the broilers. Approximately two thirds of all $\mathrm{P}$ contained in the grains and seeds used in the diet formulation are covalently linked to a cyclic structure of six carbon atoms forming what is known as phytate (SELLE et al., 2009). However, the phytate P can only be used after the action of the phytase enzyme which hydrolyses the phosphate groups of phytate making them available for absorption and metabolism. Since birds synthesize phytase in low quantity and activity (HAN et al., 2009), microbial phytases been added to the diet and researches report the benefits of its use in the broiler nutrition (CARDOSO JUNIOR et al., 2010; SANTOS et al., 2008).

However, there is concern about up to what level can crude protein be reduced without affecting the performance of broilers from 22 to 35 days old. Furthermore, it is important to ensure that the added phytase to the diet is effective to overcoming the deficiency of available phosphorus in the feed caused by the percentual reduction of inorganic phosphate.

Therefore, the objective of this work was to evaluate the effect of diets with reduced levels of crude protein, available phosphorus, and calcium, supplemented with phytase and amino acids about the performance, tibia ash, yield (carcass, cuts and abdominal fat), energetic and metabolizable value of the diet, besides the use of nitrogen and phosphorus by the broilers in the 22 to 35 days old phase.

\section{MATERIAL AND METHODS}

One performance experiment and another of metabolism were simultaneously conducted in the Poultry Science Sector of the Animal Science Department of the Federal University of Lavras to evaluate diets with reduced levels of crude protein (CP), available phosphorus (aP) and calcium $(\mathrm{Ca})$, supplemented with phytase and amino acids, given to broiler chickens in the period from 22 to 35 days old.

In both experiments five feeds based on corn and soybean meal (Table 1) were evaluated, being that one of them was denominated control diet and it was formulated without phytase according to the nutritional recommendations of Rostagno et al. (2005). The other four diets were supplemented with phytase $(80 \mathrm{~g}$ of phytase/ton of diet) and formulated with reduction of aP and $\mathrm{Ca}$ corresponding to, respectively, 0.15 and 0.3 percentage points in relation to the control, keeping the $\mathrm{Ca}$ aP ratio in $2: 1$. One of the diets containing phytase provided the same level of CP that the control diet (19\% of $\mathrm{CP}$ ) and for the three remaining, one percentage point of CP was gradually reduced associated with the use of synthetic amino acids according to the nutritional requirements of broilers described by Rostagno et al. (2005).

All the diets were isoenergetic and formulated based on digestible amino acids maintaining the ideal rate of the amino acids with lysine. The protein contents of the amino acids were not considered for the calculation of the $\mathrm{CP}$ level in the diets. The dietary electrolytic balance was calculated according to the description by Mongin (1981) and remained constant between the diets by use of potassium carbonate whenever needed.

In the performance assay, 750 male chicks of the commercial lineage Cobb-500 were acquired with one day old and reared until 21 days old with a diet based on corn and soybean meal formulated to meet their nutritional requirements (ROSTAGNO et al., 2005). On the $22^{\text {nd }}$ day, the birds were individually weighed, separated by weight ranges and transferred to a masonry shed so that each boxe $\left(3 \mathrm{~m}^{2}\right.$ each) containing 25 broilers had the initial average weight similar between one another $(1,005.00 \pm$ $2.7 \mathrm{~g})$. After this distribution, water and the experimental diets were offered ad libitum in the period from 22 to 35 days old. The experimental design was completely randomized with six replicates of 25 birds for each experimental diet evaluated. Each boxe was prepared with a wood shaving litter and contained a pendulous feeder and drinker, and an incandescent lamp of 100 watts of manner that the lighting of the shed was constant. The minimum and maximum temperatures in the shed were, respectively, $16.2^{\circ} \mathrm{C}\left(\right.$ lower $15^{\circ} \mathrm{C}$ ) and $26.8^{\circ} \mathrm{C}$ (higher $28^{\circ} \mathrm{C}$ ). The feed intake, weight gain, and feed conversion of the broilers were evaluated in the period from 22 to 35 days old. Besides that, at 35 days old, four birds from each experimental plot were slaughtered by cervical dislocation (resulting in a total of 24 broilers slaughtered per treatment), when the left tibia of two birds were removed for the determination of tibia ashes (SILVA, 2002) and two birds were used to quantify the yields of carcass, breast, thigh + drumstick and abdominal fat percentage. 
Table 1 - Composition of the experimental diets.

\begin{tabular}{|c|c|c|c|c|c|}
\hline \multirow[b]{2}{*}{ Ingredients (\%) } & \multirow[b]{2}{*}{ Control $^{2}$} & \multicolumn{4}{|c|}{ Crude protein level $^{1}$} \\
\hline & & $19.0 \%$ & $18.0 \%$ & $17.0 \%$ & $16.0 \%$ \\
\hline Corn & 64.772 & 67.051 & 69.626 & 71.806 & 74.076 \\
\hline Soybean meal & 28.356 & 27.947 & 25.381 & 22.885 & 20.373 \\
\hline Soybean oil & 3.075 & 2.304 & 1.972 & 1.774 & 1.546 \\
\hline Dicalcium phosphate & 1.710 & 0.870 & 0.880 & 0.900 & 0.907 \\
\hline Limestone & 0.850 & 0.580 & 0.589 & 0.589 & 0.598 \\
\hline Salt & 0.470 & 0.470 & 0.470 & 0.470 & 0.470 \\
\hline L-lysine & 0.224 & 0.231 & 0.312 & 0.392 & 0.471 \\
\hline DL-methionine & 0.224 & 0.221 & 0.243 & 0.265 & 0.286 \\
\hline L-arginine & 0.000 & 0.000 & 0.017 & 0.093 & 0.170 \\
\hline L-threonine & 0.050 & 0.050 & 0.086 & 0.121 & 0.157 \\
\hline L-glycine + serine & 0.000 & 0.000 & 0.011 & 0.106 & 0.200 \\
\hline L-valine & 0.018 & 0.018 & 0.061 & 0.104 & 0.147 \\
\hline L-isoleucine & 0.000 & 0.000 & 0.021 & 0.066 & 0.111 \\
\hline L-tryptophan & 0.000 & 0.000 & 0.000 & 0.003 & 0.017 \\
\hline Vitamin premix ${ }^{3}$ & 0.100 & 0.100 & 0.100 & 0.100 & 0.100 \\
\hline Mineral premix ${ }^{4}$ & 0.050 & 0.050 & 0.050 & 0.050 & 0.050 \\
\hline Choline chloride $60 \%$ & 0.050 & 0.050 & 0.050 & 0.050 & 0.050 \\
\hline Salinomycin $12 \%$ & 0.050 & 0.050 & 0.050 & 0.050 & 0.050 \\
\hline Phytase - Ronozyme ${ }^{\circledR} \mathrm{NP}(\mathrm{M})$ & 0.000 & 0.008 & 0.008 & 0.008 & 0.008 \\
\hline Potassium carbonate & 0.000 & 0.000 & 0.073 & 0.143 & 0.213 \\
\hline \multicolumn{6}{|l|}{ Calculated composition } \\
\hline Crude protein $(\%)$ & 19.00 & 19.00 & 18.00 & 17.00 & 16.00 \\
\hline Metabolizable energy (Kcal/Kg) & 3,100 & 3,100 & 3,100 & 3,100 & 3,100 \\
\hline Available phosphorus (\%) & 0.412 & 0.262 & 0.262 & 0.262 & 0.262 \\
\hline Calcium $(\%)$ & 0.824 & 0.524 & 0.524 & 0.524 & 0.524 \\
\hline Lysine (\%) & 1.073 & 1.073 & 1.073 & 1.073 & 1.073 \\
\hline Methionine + cystine $(\%)$ & 0.772 & 0.773 & 0.773 & 0.773 & 0.773 \\
\hline Arginine $(\%)$ & 1.192 & 1.187 & 1.127 & 1.127 & 1.127 \\
\hline Threonine $(\%)$ & 0.697 & 0.696 & 0.697 & 0.697 & 0.697 \\
\hline Glycine + serine $(\%)$ & 1.740 & 1.739 & 1.656 & 1.656 & 1.656 \\
\hline Valine $(\%)$ & 0.826 & 0.826 & 0.826 & 0.826 & 0.826 \\
\hline Isoleucine $(\%)$ & 0.745 & 0.743 & 0.719 & 0.719 & 0.719 \\
\hline Tryptophan (\%) & 0.207 & 0.206 & 0.192 & 0.182 & 0.182 \\
\hline Leucine $(\%)$ & 1.606 & 1.615 & 1.554 & 1.492 & 1.430 \\
\hline Histidine (\%) & 0.491 & 0.492 & 0.468 & 0.444 & 0.421 \\
\hline Phenylalanine (\%) & 0.700 & 0.699 & 0.701 & 0.701 & 0.701 \\
\hline Phenylalanine + tyrosine $(\%)$ & 1.486 & 1.485 & 1.406 & 1.326 & 1.247 \\
\hline Sodium $(\%)$ & 0.205 & 0.206 & 0.206 & 0.206 & 0.206 \\
\hline Potassium (\%) & 0.881 & 0.880 & 0.833 & 0.786 & 0.738 \\
\hline Chloride (\%) & 0.327 & 0.328 & 0.328 & 0.328 & 0.327 \\
\hline D.E.B. $(\mathrm{mEq} / \mathrm{kg})^{5}$ & 176 & 176 & 176 & 176 & 176 \\
\hline
\end{tabular}

${ }^{1}$ Diets supplemented with phytase and formulated with reduced levels of crude protein, available phosphorus and calcium when compared to the control diet.

${ }^{2}$ Diet without phytase and formulated to meet the nutritional requirements of broilers ( 22 to 35 days of age), according to Rostagno et al. (2005).

${ }^{3}$ Content $/ \mathrm{kg}$ of feed: $12,500 \mathrm{IU}$ vit. A; $5,760 \mathrm{IU}$ vit. $\mathrm{D}_{3} ; 150 \mathrm{mg}$ vit. $\mathrm{E} ; 4 \mathrm{mg}$ vit. $\mathrm{K}_{3} ; 3 \mathrm{mg}$ vit. $\mathrm{B}_{1} ; 9 \mathrm{mg}$ vit. $\mathrm{B}_{2} ; 6 \mathrm{mg}$ vit. $\mathrm{B}_{6} ; 40 \mu \mathrm{g}$ vit. $\mathrm{B}_{12} ; 80 \mathrm{mg}$ nicotinic acid; $2 \mathrm{mg}$ folic acid; $18 \mathrm{mg}$ pantothenic acid; $0.3 \mathrm{mg}$ biotin.

${ }^{4}$ Content/kg of feed: $50 \mathrm{mg} \mathrm{Fe} ; 10 \mathrm{mg} \mathrm{Cu} ; 50 \mathrm{mg} \mathrm{Zn;} 80 \mathrm{mg} \mathrm{Mn} ; 1 \mathrm{mg} \mathrm{I} ; 1 \mathrm{mg} \mathrm{Co} ; 0.30 \mathrm{mg} \mathrm{Se}$.

${ }^{5}$ D.E.B. $=$ dietary electrolyte balance. The D.E.B. was calculated using the equation proposed by Mongin (1981), which correlates the calculated concentrations of sodium, potassium and chloride $\left(\mathrm{Na}^{+}+\mathrm{K}^{+}-\mathrm{Cl}^{-}\right)$. 
In the metabolism assay, 90 male Cobb-500 chicks received a standard diet based on corn and soy bean meal, in the period from 1 to 27 days old (ROSTAGNO et al., 2005). On the $28^{\text {th }}$ day, the broilers were individually weighed, separated by weight ranges and transferred to a metabolism room in a completely randomized design with six replicates of three birds. Each metabolic cage had a drinker, a feeder and a collector tray of excreta. The experimental period was of seven days, when there were four days for adaptation to the diets and facilities and three days (RODRIGUES et al., 2005) of total excreta collection. The excreta were collected daily in the morning, packed in plastic bags and stored in a freezer until the end of the collection period when the excreta were finally unfrozen, weighed, homogenized and pre-dried in air circulating stove at $60^{\circ} \mathrm{C}$ for 72 hours. After that, the samples (diets and excreta) were ground and used for the determination of dry matter, gross energy, nitrogen (AOAC, 2005) and phosphorus (SILVA, 2002). The apparent metabolizable energy corrected by the nitrogen balance (AMEn) was calculated according to Matterson et al. (1965). The metabolizability coefficient (MC) of the experimental diets and the apparent retention coefficients (RC) of the nitrogen and phosphorus were calculated based on the dry matter, using the equation: $\mathrm{MC}$ or $\mathrm{RC}=[$ ( $\mathrm{g}$ of ingested nutrient - $g$ of excreted nutrient)/g de ingested nutrient] $x$ 100.

The variance analysis of the data was realized using the statistic software SISVAR (FERREIRA, 2011) and when significant the means of the treatments were initially compared by the Scott-Knott test at $5 \%$ of probability and subsequently at $1 \%$ of probability to verify the lowest level of significance for each variable evaluated.

\section{RESULTS AND DISCUSSION}

The diets did not influence $(\mathrm{P}>0.05)$ the feed intake, weight gain and feed conversion of the broilers in the period from 22 to 35 days old (Table 2). Therefore, the birds which received diets formulated with reduced levels of crude protein (CP), available phosphorus (aP) and calcium $(\mathrm{Ca})$, supplemented with phytase and amino acids, showed similar performance to that of the birds fed with control diet ( $19 \%$ of CP, $0.412 \%$ of aP, and $0.824 \%$ of $\mathrm{Ca}$ ). These results indicate that it is possible to reduce the dietary protein level up to $16 \%$ without compromising the performance, since synthetic amino acids are added to the diet according to the requirements and ideal amino acids profile recommended from the literature for these animals. In similar research using the concept of ideal protein for feed formulation, Oliveira et al. (2010) verified that the CP can be reduced from 21.6 up to $17.6 \%$ without harming the performance of broilers from 22 to 42 days old, even when reared in heat stress environment. However, Vasconcellos (2010) reported that the broilers performance ( 21 to 42 days old) was negatively affected by reducing the $\mathrm{CP}$ to $15 \%$, even adding amino acids to meet the nutritional recommendations of Rostagno et al., (2005). Normally, the reduction of dietary $\mathrm{CP}$ is done by decreasing the percentage amount of soybean meal which is rich in potassium, thus, there can be alteration in the electrolytic balance of the diet which, according to Aftab (2006), can contribute to a worse broiler performance. It is important to highlight that the diets with reduced level of $\mathrm{CP}$ in this study showed the same electrolytic balance of the control diet by adding adequate concentrations of potassium carbonate, what might have positively influenced to promote a similar performance in all evaluated protein levels.

Recently, Cardoso Júnior (2010) reported benefits of phytase in the nutrition of broilers and according to Choct (2006), the phytase can improve the use of the phytate phosphorus of the feed in up to $70 \%$. Therefore, it is concluded that the phytase used in this work was efficient in acting over the phytate of the plant feed, providing $\mathrm{P}$ and $\mathrm{Ca}$ for the development of the birds. Based on these performance results, the use of this enzyme ( $80 \mathrm{~g}$ of phytase/ton of diet) allows the aP and $\mathrm{Ca}$ in the diet to be reduced respectively, to 0.262 and $0.524 \%$.

Still in Table 2, it can be observed that the tibia ashes were not harmed $(\mathrm{P}>0.05)$ by nutritional reduction of the diets, suggesting again that the phytase increased the availability of minerals like the $\mathrm{P}$ and $\mathrm{Ca}$. Phytase is an enzyme that hydrolyzes the phosphoester bonds of the phytate releasing the phosphate groups which can be then absorbed in the intestine and used by the bird for the formation and maintenance of the bone structure, among others. Furthermore, the reduction in the phosphorylation degree of the phytate decreases its chelating capacity with cations, as the $\mathrm{Ca}^{2+}$. Therefore, phytase increases the retention of dietary $\mathrm{Ca}$ by reducing the complexation rate between $\mathrm{Ca}$ and phytate, emphasizing that nutrients chelated to the phytate cannot be absorbed in the intestine (SELLE et al., 2009). 


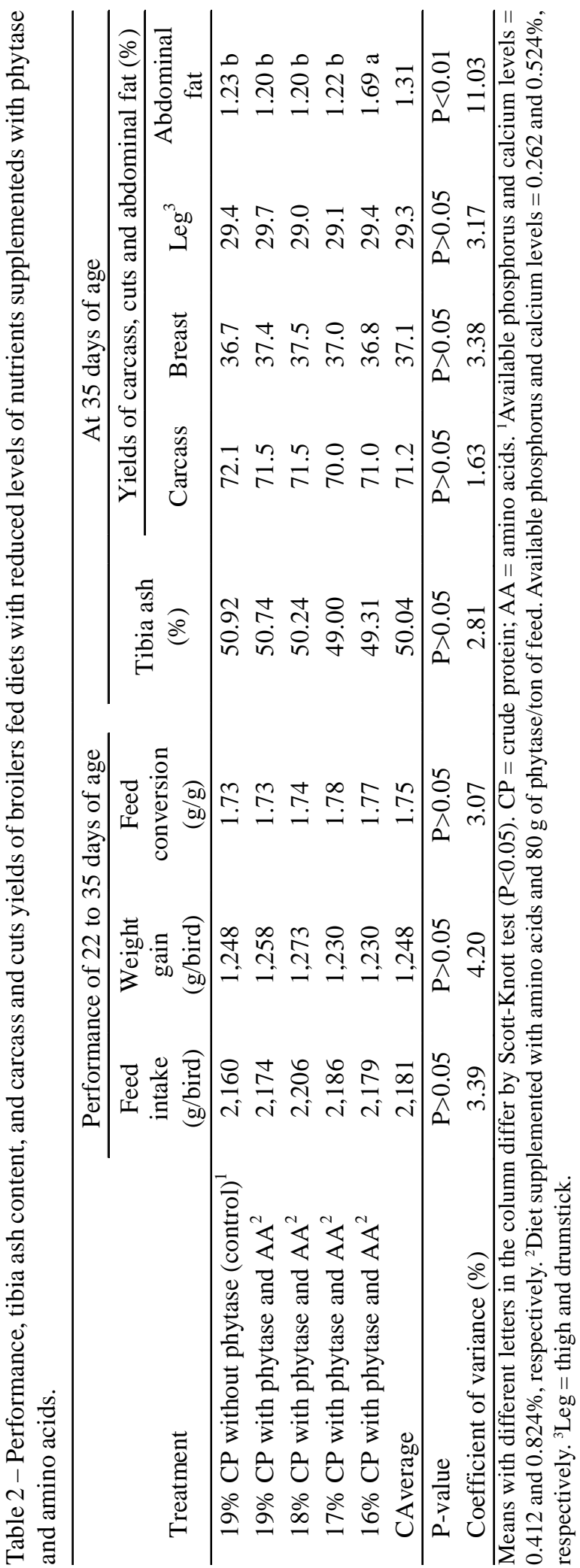

The reduction in the levels of $\mathrm{CP}$, aP and $\mathrm{Ca}$ associated by the use of amino acids and phytase did not influence $(\mathrm{P}>0.05)$ the yields of carcass, breast, and thigh + drumstick (Table 2). However, the broilers fed diet with $16 \%$ of CP showed abdominal fat content $40 \%$ higher than $(\mathrm{P}<0,01)$ to that recorded for the birds in the remaining treatments. A hypothesis to explain this increase in abdominal fat is based on the caloric increment of the nutrients. One protein gram has higher caloric increment than one carbohydrate or fat gram, that is, it requires a greater amount of energy to be digested, absorbed and metabolized (Musharaf; Latshaw, 1999). So, when the CP content in the feed is reduced the dietary net energy is increased, being a portion this energy used for maintenance and production, and its excess stored as body fat. Nowadays, the modern consumer normally chooses nutritionally healthy food and, therefore, containing less fat. Thus, it should be considered that diet formulated with $16 \%$ of CP can reduce the production profits, in commercial scale, when the abdominal fat is removed during the bird processing. Similar to the results of this work, Dari et al. (2005), Faria Filho et al. (2005) and Gomide et al. (2007) verified increase of abdominal fat in broilers fed diets containing reduced level of CP and synthetic amino acids.

In the metabolism assay, it was verified that the diets with $19 \%$ of CP showed lower $(\mathrm{P}<0.01)$ value of apparent metabolizable energy corrected by the nitrogen balance (AMEn) and lower $(\mathrm{P}<0.01)$ metabolizability coefficient of dry matter (MCDM) (Table 3), indicating that the diets formulated with reduced $\mathrm{CP}$ and synthetic amino acids were more energetically efficient and showed better MCDM. Results similar to this study were also described by Silva et al. (2008) with younger broilers (14 to 21 days of age).

Knowing that the protein reduction from the diet decreased $(\mathrm{P}<0.01)$ the excretion of nitrogen $(\mathrm{N})$ by birds and that diets with reduced $\mathrm{CP}$ and adequately supplemented with synthetic amino acids have amino acid profile closer to the needs of these animals, it is probable that the increase of AMEn of the diets formulated with 16 to $18 \%$ of CP is correlated to an economy of energy in amino acids catabolism and excretion of $\mathrm{N}$.

According to Refstie et al. (1999), the increase in the amount of soybean meal in the diet reduces the digestibility of dry matter and increases the viscosity of the intestinal contents due to the presence of non-starch polysaccharides (NSPs) in this ingredient. Therefore, the greater NSPs content in the diets with $19 \%$ of CP, due to the greater inclusion of soybean meal, may have affected the nutrient digestibility decreasing the MCDC of these diets.

Ciênc. agrotec., Lavras, v. 36, n. 1, p. 100-107, jan./fev., 2012 
The intake, excretion and retention of $\mathrm{N}$ and phosphorus $(\mathrm{P})$ were influenced $(\mathrm{P}<0.05)$ by the diet (Table 3 ). The birds excreted $16 \%$ less $\mathrm{N}$, when fed diet containing from 16 to $18 \%$ of CP. As expected, the birds which received the diets with $19 \%$ of CP excreted more N and, consequently, showed less $\mathrm{N}$ retention coefficient corroborating with the results of Corzo et al. (2005). The phytase did not improve the $\mathrm{N}$ retention because there wasn't difference for this parameter between the two diets with $19 \%$ of CP. Although the effect of phytase in increasing the utilization of the phytate $\mathrm{P}$ of the diet is well reported in the literature (GOMIDE et al., 2011; SANTOS et al., 2008; SILVA et al., 2008), its effect over the protein of the diet isn't well established yet, which requires more study in this area of research.

The birds fed diets containing phytase and $0.262 \%$ of aP showed lower $(\mathrm{P}<0.01)$ intake and excretion of $\mathrm{P}$ being this reduction of the intake justified by the lower rate of inclusion of dicalcium phosphate in the diet. On the other hand, the decrease in the $\mathrm{P}$ excretion can be explained due to lower intake of aP associated to the fact that the phytase increased the use of phytate $\mathrm{P}$ of the plant ingredients decreasing its excretion. These results corroborate with the works of Silva et al. (2008) and Gomide et al. (2011) who verified that broilers fed diets containing reduced aP content and phytase consume and excrete less $\mathrm{P}$. The diets with 16 to $18 \%$ of CP, $0.262 \%$ of aP and supplemented with phytase resulted in the better retention of $\mathrm{P}(\mathrm{P}<0.01)$ being this improvement very important because it reflects the better $\mathrm{P}$ utilization by the birds which meets the current need of optimization of the livestock production with environmental responsibility.
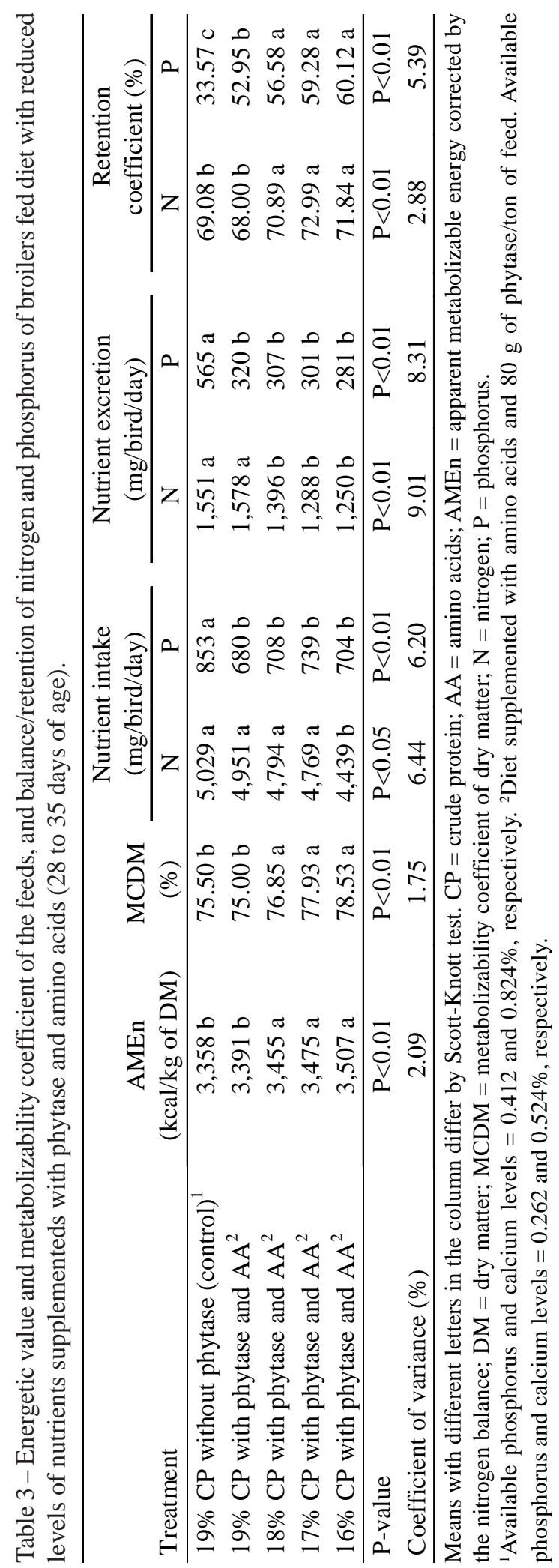


\section{CONCLUSION}

When the broiler feed is supplemented with phytase and amino acids it is possible to reduce the levels of crude protein, available phosphorus and calcium to 16; 0.262 and $0.524 \%$, respectively. Besides improving the energetic value and metabolizability coefficient of the diet and to increase the retention of nitrogen and phosphorus, this nutritional reduction does not compromises the performance, tibia mineralization, and yields of carcass and noble cuts of broilers from 22 to 35 days of age.

\section{ACKNOWLEDGMENTS}

To the Conselho Nacional de Desenvolvimento Científico e Tecnológico $(\mathrm{CNPq})$ for financing the project, to the Fundação de Amparoà Pesquisa doEstado de Minas Gerais (FAPEMIG) for financial support by means of the Programa Pesquisador Mineiro (PPM), and to the Instituto Nacional de Ciência e Tecnologia em Ciência Animal (INCT-CA).

\section{REFERENCES}

AFTAB, U.; ASHRAF, M.; JIANG, Z. Low protein diets for broilers. World's Poultry Science Journal, Cambridge, v.62, n.4, p.688-701, dec. 2006.

\section{ASSOCIATION OF OFFICIALANALYTICAL} CHEMISTS (AOAC). 2005. Official methods of analysis, 18th edn. AOAC, Maryland, 1094p.

CARDOSO JÚNIOR, A. et al. Levels of available phosphorus and calcium for broilers from 8 to 35 days of age fed rations containing phytase. Revista Brasileira de Zootecnia, Viçosa, v.39, n.6, p.1237-1245, jun. 2010.

CHOCT, M. Enzymes for the feed industry: past, present and future. World's Poultry Science Journal, Cambridge, v.62, n.1, p.5-16, mar. 2006.

CORZO, A. et al. Response of broiler chicks to essential and non-essential amino acid supplementation of low crude protein diets. Animal Feed Science and Technology, Amsterdam, v.118, n.3-4, p.319-327, feb. 2005.

DARI, R.L. et al. Use of digestible amino acids and the concept of ideal protein in feed formulation for broilers. Journal of Applied Poultry Research, Athens, v.14, n.2, p.195-203, 2005.

FARIA FILHO, D.E. et al. Protein levels and environmental temperature effects on carcass characteristics, performance, and nitrogen excretion of broiler chickens from 7 to 21 days of age. Brazilian Journal of Poultry Science, Campinas, v.7, n.4, p.247253, oct./dec. 2005.

FERREIRA, D.F. Sisvar: A computer statistical analysis system. Ciência e Agrotecnologia, Lavras, v.35, n.6, p.1039-1042, nov./dez. 2011.

GOMIDE, E. M. et al. Nitrogen, calcium and phosphorus balance of broilers fed diets with phytase and crystalline amino acids. Ciência e Agrotecnologia, Lavras, v.35, n.3. p. 591-597, maio/jun., 2011.

GOMIDE, E.M. et al. Planos nutricionais com a utilização de aminoácidos e fitase para frangos de corte mantendo o conceito de proteína ideal nas dietas. Revista Brasileira de Zootecnia, Viçosa, v.36, n.6, p.1769-1774, nov./dez. 2007.

HAN, J. C. et al. Evaluation of equivalency values of microbial phytase to inorganic phosphorus in 22- to 42day-old broilers. Journal of Applied Poultry Research, Athens, v.18, n.4, p.707 - 715, dec. 2009.

MATTERSON, L.D. et al. The metabolizable energy of feed ingredients for chickens. Storrs: The University of Connecticut-Agricultural Experiment Station, p.3-11, 1965 (Research Report, 7).

MONGIN, P. Recent advances in dietary anion-cation balance: application in poultry. Procedure Nutrition Society, v.40, p.285-294, 1981.

MUSHARAF, N.A.; LATSHAW, J.D. Heat increment as affected by protein and amino acid nutrition. World's Poultry Science Journal, Cambridge, v.55, n.3, p.233240, 1999.

OLIVEIRA, W.P. de et al. Redução do nível de proteína bruta em rações para frangos de corte em ambiente de estresse por calor. Revista Brasileira de Zootecnia, Viçosa, v.39, n.5, p.1092-1098, mai. 2010.

REFSTIE, S. et al. Nutrient digestibility in Atlantic salmon and broiler chickens related to viscosity and non-starch polysaccharide content in different soybean products. Animal Feed Science and Technology, Amsterdam, v.79, n.4, p.331-345, jun. 1999. 
RODRIGUES, P.B. et al. Influência do tempo de coleta e metodologias sobre a digestibilidade e o valor energético de rações para aves. Revista Brasileira de Zootecnia, Viçosa, v.34, n.3, p.882-889, mai./jun. 2005.

ROSTAGNO, H.S. et al. Tabelas brasileiras para aves e suínos: composição de alimentos e exigências nutricionais. 2. ed. Viçosa: UFV, 2005. 186 p.

SANTOS, F.R. et al. Effect of phytase supplementation in diets on nutrient digestibility and performance in broiler chicks. Journal of Applied Poultry Research, Athens, v.17, n.2, p.191-201, 2008.

\section{SELLE, P.H.; COWIESON, A.J.; RAVINDRAN, V.}

Consequences of calcium interactions with phytate and phytase for poultry and pigs. Livestock Science, v.124, n.1-3, p. 126-141, sep. 2009.

SILVA, D.J. Análise de alimentos: métodos químicos e biológicos. 3.ed. Viçosa:UFV, 2002. 235p.

SILVA, Y.L. da et al. Níveis de proteína e fósforo em rações com fitase para frangos de corte, na fase de 14 a 21 dias de idade: 2 . valores energéticos e digestibilidade de nutrientes. Revista Brasileira de Zootecnia, Viçosa, v.37, n.3, p.469-477, mar. 2008.

VASCONCELLOS, C.H. de F. et al. Efeito de diferentes níveis de proteína bruta sobre o desempenho e composição de carcaça de frangos de corte machos de 21 a 42 dias de idade. Ciência e Agrotecnologia, Lavras, v.34, n.4, p.1039-1048, jul./ago. 2010. 